\title{
Meningkatkan Hasil Belajar PJOK Materi Senam Lantai dengan Metode Latihan Berulang pada Siswa Kelas IV SDN 3 Kopang Tahun Pelajaran $2018 / 2019$
}

\author{
Husnan \\ Guru Pjok SDN 3 Kopang Kabupaten Lombok Tengah
}

\begin{abstract}
Abstrak. Penelitian ini adalah Penelitian Tindakan Kelas (PTK). yaitu penelitian yang di lakukan oleh guru di dalam kelasnya sendiri melalui refleksi diri, dengan tujuan untuk memperbaiki kinerjanya sebagai guru, sehingga hasil belajar siswa menjadi meningkat (Arikunto,2006; 4). Penelitian ini dilaksanakan di SDN 3 Kopang Kelas IV dengan materi Senam pada semester I tahun pelajaran 2018 / 2019 dengan jumlah Subyek penelitian sebanyak 13 orang dan hasilnya seperti yang telihat pada Bab IV yaitu sebagai berikut : Hasil belajar siswa pada siklus I dengan menerapkan pola latihan berulang diperoleh nilai rata-rata hasil belajar siswa adalah 67,6 pada siklus I ketuntasan belajar mencapai $31 \%$ atau 4 siswa sudah tuntas belajar, dan siswa yang belum tuntas sebanyak 9 orang dengan menerapkan pola latihan berulang diperoleh nilai rata-rata hasil belajar siswa 85,61 pada siklus II dengan ketuntasan belajar mencapai $92 \%$ atau ada 12 siswa sudah tuntas belajar dan 1 orang belum tuntas dengan persentase sebesar $8 \%$,, bisa memamfaatkan waktu dengan baik. Begitu juga dengan ketuntasan klasikal yang di persyaratkan sebesar $\geq 80$ sudah tercapai maka dengan demikian penelitian ini dihentikan sampai pada siklus II. Dengan demikian dapat ditarik kesimpulan bahwa dengan menggunakan metode latihan berulang dapat meningkatkan hasil belajar Senam lantai di Kelas IV SDN 3 Kopang tahun Pelajaran 2018 / 2019
\end{abstract}

\section{Kata Kunci; Latihan Berulang, Pjok, Hasil Belajar}

\section{PENDAHULUAN}

Cabang olah raga senam mulai diajarkan sejak di Sekolah Dasar hingga perguruan tinggi, tidak ada satu cabang olah ragapun yang dilaksanakan dengan baik tampa dukungan dari kualitas fisik pelakunya. Kualitas fisik seperti kecepatan, misalnya sangat diperlukan dalam bidang olah raga seperti atetik, permainan, bela diri, dan olah raga lainya. Demikian juga dengan kualitas kekuatan, yang diperlukan oleh hampir seluruh cabang olah raga yang ada.

Gagasan tentang pentingnya kualitas fisik dalam mendukung berhasilnya keterampilan yang dilakukan berlaku juga dalam cabang olah raga senam.Seseorang tidak akan mampu melakukan keterampilan senam dengan baik, jika ia tidak memiliki persyarataan kualitas fisik yang diperlukan dalam gerak tersebut, bergantung pada kelemahannya, pelaksanaan keterampilan yang dilakukan pasti akan menunjukkan ketidak sempurnaan.
Oleh karena itu perlu disadari bahwa penting kiranya guru menyadari bahwa untuk keberhasilan pembelajaran senam di sekolah, siswa perlu dibekali dengan seperangkat kualitas fisik yang diperlukan untuk melakukan keterampilan senam. Masalahnya adalah bagaimanakah membekali persyaratan fisik ini kepada siswa, apakah harus secara khusus dilakukan dalam bentuk peningkatan kondisik fisik, ataukah ada cara lain?

Senam kependidikan yang dilaksanakan disekolah akan sangat bermamfaat bagi peningkatan berbagai asfek , khususnya peningkatan asfek fisik. Melalui berbagai aktivitas yang dilakukan dalam pembelajaran senam, siswa hendaknya dapat meningkatkan kualitas pembeajaran senam, siswa hendaknya dapat meningkatkan kualitas fisiknya, sehingga meningkat pula kesiapan untuk menguasai keterampilan - keterampilan senam yang dipelajarinya. 
Ide dasarnya adalah bahwa pembelajaran senam yang dilaksanakan harus mampu meningkatkan kebugaran fisik anak, dan dari kebugaran itu anak akan meningkatkan pula keterampilan senammya, jdi sifatkan timbal balik, senam untuk kebugaran, kebugaran untuk senam.

Namun perlu disadari bahwa peningkatan kualitas fisik bukanlah sesuatu yang dapat dilakukan cukup dalam lima atau sepuluh menit, melainkan dalam keseluruhan program pembelajaran senam, sehingga berdasarkan hasil ulangan yang dilakukan di SDN 3 Kopang di kelas IV materi senam lantai yang diikuti oleh 13 orang siswa ternyata hasilnya masih jauh dari yang diharapkan dari 13 orang peserta yang tuntas hanya 5 orang dengan persentase ketuntasan sebesar $38 \%$, dan siswa yang belum tuntas sebanyak 8 orang dengan persentase sebesar $62 \%$, sedangkan Kriteria ketuntasan Minimal yang dipatok di SDN 3 Kopang Mata pelajaran PJOK tahun pelajaran 2018/ 2019 adalah 70 dengan ketuntasan klasikal yang dipatok sebesar $\geq 80 \%$.

Ternyata rendahnya hasil belajar siswa dikarenakan penggunaan metode yang kurang tepat dimana guru tidak menyesuaikan antara metode dan materi yang akan di ajarkan, sehingga peneliti akan mencoba untuk menawarkan salah satu metode yaitu metode latihan berulang untuk mengajarkan materi senam lantai yang membutuhkan latihan yang terus menerus sehingga menjadi terbiasa tidak cukup satu kali untuk melatih kebugaran, sehingga latihan yang berulang ulang bisa menjadi solusi dalam pemecahan masalah pembelajaran pada materi senam lantai. Dana penulis mencoba untuk mengambil judul penelitian yaitu : "Meningkatkan hasil belajar PJOK materi Senam lantai dengan metode latihan berulang pada siswa kelas IV SDN 3 Kopang tahun pelajaran 2018/2019"

\section{Rumusan Masalah}

Berdasarkan latar belakang maka rumusan dalam penelitian ini adalah Bagaimanakah Meningkatkan hasil belajar PJOK materi Senam lantai dengan metode latihan berulang pada siswa kelas IV SDN 3 Kopang tahun pelajaran 2018/2019”

\section{Tujuan Penelitian}

Adapun tujuan penelitian ini adalah untuk Meningkatkan hasil belajar PJOK materi Senam lantai dengan metode latihan berulang pada siswa kelas IV SDN 3 Kopang tahun pelajaran 2018/2019"

\section{Manfaat Penelitian}

Dengan penelitian tindakan kelas ini diharapkan dapat memberikan motivasi belajar hususnya materi senam lantai sehinggga siswa dapat mengembangkan keterampilan dalam melakukan senam lantai.

\section{LANDASAN TEORI DAN KAJIAN PUSTAKA \\ Hakikat Pendidikan Jasmani dan \\ Kesehatan}

Pendidikan jasmani pada hakikatnya adalah proses pendidikan yang memanfaatkan aktivitas fisik untuk menghasilkan perubahan holistik dalam kualitas individu, baik dalam hal fisik, mental, serta emosional. Pendidikan jasmani memperlakukan anak sebagai sebuah kesatuan utuh, mahluk total, daripada hanya menganggapnya sebagai seseorang yang terpisah kualitas fisik dan mentalnya.

Pada kenyataannya, pendidikan jasmani adalah suatu bidang kajian yang sungguh luas. Titik perhatiannya adalah peningkatan gerak manusia. Lebih khusus lagi, penjas berkaitan dengan hubungan antara gerak manusia dan wilayah pendidikan lainnya: hubungan dari perkembangan tubuh-fisik dengan pikiran dan jiwanya. Fokusnya pada pengaruh perkembangan fisik terhadap wilayah pertumbuhan dan perkembangan aspek lain dari manusia itulah yang menjadikannya unik. Tidak ada bidang tunggal lainnya seperti pendidikan jasmani yang berkepentingan dengan perkembangan total manusia.

Per definisi, pendidikan jasmani diartikan dengan berbagai ungkapan dan kalimat. Namun esensinya sama, yang jika disimpulkan bermakna jelas, bahwa pendidikan jasmani memanfaatkan alat fisik untuk mengembangan keutuhan manusia. Dalam kaitan ini diartikan bahwa melalui fisik, aspek mental dan emosional pun turut terkembangkan, bahkan dengan penekanan 
yang cukup dalam. Berbeda dengan bidang lain, misalnya pendidikan moral, yang penekanannya benar-benar pada perkembangan moral, tetapi aspek fisik tidak turut terkembangkan, baik angsung maupun secara tidak langsung.

\section{Pengertian Senam}

Ada beberapa pengertian tentang senam dengan mengutip pernyataan Agus Mahendra (2000: 7), senam dalam bahasa Indonesia sebagai salah satu cabang olahraga merupakan terjemahan langsung dari bahasa Inggris Gymnastics. Sedangkan Imam Hidayat dalam Hendra Agusta (2009: 9), mendefinisikan senam sebagai "... suatu latihan tubuh yang terpilih dan dikonstruk dengan sengaja, dilakukan secara sadar dan terencana disusun secara sistematis dengan tujuan meningkatkan kesegaran jasmani, mengembangkan keterampilan, dan menanamkan nilai-nilai mental spiritual."

Menurut Muhajir (2006: 71) senam adalah kegiatan utama paling bermanfaat untuk mengembangkan komponen fisik dan kompnen gerak. Senam guling belakang merupakan salah satu jenis senam lantai yang dilakukan dengan gerak-gerak fisik sistematis dengan tujuan membentuk dan mengembangkan kepribadian secara harmonis. Senam mempunyai banyak jenis, diantaranya adalah senam lantai senam ketangkasan, senam aerobic, maupun senam ritmik.

Dari pendapat di atas dapat disimpulkan bahwa, senam adalah sebagai salah satu cabang olahraga merupakan terjemahan langsung dari bahasa Inggris Gymnastics. Senam merupakan suatu latihan tubuh yang terpilih dan dikonstruk dengan sengaja, dilakukan secara sadar dan terencana disusun secara sistematis dengan tujuan meningkatkan kesegaran jasmani, mengembangkan keterampilan, dan menanamkan nilai-nilai mental spiritual

\section{Senam Ketangkasan atau Lomba}

Senam ada 2 jenis yaitu senam ketangkasan atau lomba dengan senam kependidikan. Senam ketangkasan atau senam lomba menurut FIG yang telah dikutip oleh (Agus Mahendra, 2013: 4), dibagi menjadi 6 kelompok, yaitu : (a) Senam artistic, (b) Senam ritmik sportif, (c) Senam akrobatik, (d) Senam aerobik sport, (e) Senam trampoline, (f) Senam umum

Jenis senam ketangkasan atau senam lomba tersebut sebagian materinya yang sering diajarkan adalah senam artistik.

Senam artistik menurut Hendra

Agusta (2009: 12), senam yang menggabungkan aspek tumbling dan akrobatik untuk mendapatkan efek- efek artistik dari gerakan-gerakan yang dilakukan pada alat-alat. Senam artistik yang diajarkan di sekolah dasar adalah senam lantai atau (floor Excercise). Senam lantai (flour exercise) adalah bagian dari rumpun senam dengan istilah lantai, maka gerakan-gerakan senam lantai dilakukan di atas yang beralaskan matras, atau permadani. (http://minwarno.blogspot.com). Senam lantai sering juga disebut dengan istilah latihan bebas, sebab pada waktu melakukan gerakan atau latihannya pesenam tidak boleh menggunakan alat atau suatu benda, (http://minwarno.blogspot.com). Salah satu senam lantai adalah guling belakang.

Dari pendapat di atas dapat disimpulkan bahwa senam ketangkasan adalah senam yang sering dilombakan. Jenis senam ketangkasan tersebut, senam lantai yang sering diajarkan di sekolah dasar, dan salah satu materinya adalah guling belakang.

\section{Pengertian Guling Belakang}

Diantara bermacam-macam jenis senam tidak semua senam diberikan di sekolah, salah satunya adalah senam lantai, yang termasuk bagian dari senam artistik. Menurut Wuryati Soekarno (2006: 110) senam lantai adalah bagian dari rumpun senam. Sesuai dengan istilah, maka gerakangerakannya atau bentuk latihanya dilakukan di lantai atau menggunakan matras. Senam lantai pada prinsipnya disebut floor exercise, latihan senam yang dilakukan di lantai beralaskan matras dengan ukuran tertentu. Senam mempunyai banyak jenis, diantaranya adalah senam lantai senam ketangkasan, senam aerobic, maupun senam ritmik. Jenis senam tersebut mempunyai variasi gerakan yang berbeda. Gerakan- 
gerakan itu bertujuan untuk melenturkan gerak tubuh.

Senam artistik termasuk guling belakang adalah sebagai senam yang menggabungkan aspek tumbling dan akrobatik untuk mendapatkan efek artistik dari gerakan-gerakan yang dilakukan. Menurut Muhajir (2006: 72) keterampilan guling dapat divariasikan dengan mencari cara yang berbeda dalam tiga fase gerakan berguling, yaitu posisi awalan, posisi ketika melakukan guling, dan posisi akhir. Guling belakang adalah gerakan menggelundung kebelakang,

(Carapedia.com/senam_lantai_info224.html)

- Gambar senam lantai guling belakang adalah sebagai berikut :

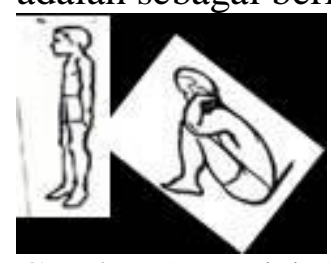

Gambar 1. Posisi Awalan Guling Belakang Sumber

Carapedia.com/senam_lantai_info224.html

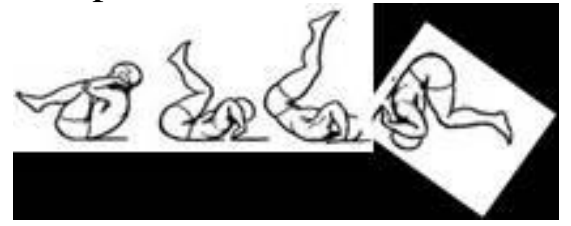

Gambar 2. Rangkaian Saat Guling Belakang Sumber :

Carapedia.com/senam_lantai_info224.html

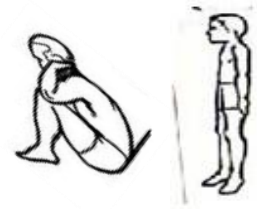

Gambar 3. Posisi Akhir Guling Belakang

Sumber :

Carapedia.com/senam_lantai_info224.html

\section{Konsep Pola Latihan Berulang.}

Dalam latihan belajar PJOK tentunya tidak asing lagi dengan istilah pendekatan (aproace), metede (method), serta (tehnique). Pengertian yang terkadang dalam ketiga istilah tersebut sangat erat dengan kegiatan pembelajaran pada umumnya, khususnya dalam pembelajaran PJOK
Pendekatan secara harfiah dari kata bahasa Inggris "approach" yang artinya penghampiran, jalan, tindakan mendekati. Secara teknis pendekatan pembelajaran dapat diartikan sebagai jalan yang digunakan oleh guru atau pembelajar untuk menciptakan suasana yang memungkinkan siswa belajar (Rosita, 2007 : 124). Belajar dalam konteks ini diartikan mengalami peristiwa itu. Lebih luas lagi, tentang proses belajar, dan tentang suasana yang dapat menciptakan terjadinya peristiwa belajar. Pendekatan bersifat konseptual artinya didalam pikiran guru yang menjadi kerangka unutk melakukan tindakan permbelajaran.

Istilah metode berasal dari bahasa Inggeris "Method" yang berarti jalan atau cara untuk mengerjakan sesuatu (a way maner of doing). Dalam pembelajaran bahasa, metode berarti sestem perencdanaan pembelajaran secara menyeluruh untuk memilih, mengorganisasikan, dan menyajikan pembelajaran bahasa secara teratur. Sebagai suatu sistem, suatu metode, terdiri atas bagian-bagian yang satu sama lain saling berhubungan. Metode bersifat prosedural, dalam arti bahwa penerapan suatu metode dalam pembelajaran PJOK harus dikerjakan menurut langkah-langkah yang teratur, secara lengkap, yaitu mulai dari perencanaan, pengajaran, penyajian pelajaran sampai dengan penilaian hasil dan proses pembelajaran.

Istilah tehnik dari tecnique yang berarti keterampilan dalam satu cabang atau kiat dalam melakukan kegiatan dalam bidang tertentu. Kaitannya dalam pengajaran PJOK teknik mengacu pada implementasi perencanaan pengajaran di luar kelas. Teknik juga diartikan sebagi suatu cara khusus/spesifik yang digunakan oleh guru dan siswa dalam melakukan suatu kegiatan. Bergantung pada guru, pada kiatnya secara individu serta bergantung pada kondisi lapangan .Problema-problema tertentu mungkin saja bisa ditangani dengan baik dengan teknik yang berbeda.

Dari uraian di atas dapat disimpulkan bahwa pendekatan bersifat konseptual artinya Pola Latihan dengan 
diberikan dengan pemberian latihan yang terus menerus bukan hanya untuk satu kali saja tetapi sampai tujuan yang ingin dicapai. Dari uraian pendekatan metode dan teknik di atas, maka dalam perencanaan penelitian tindakan pembelajaran PJOK di kelas, khususnya senam lantai menekankan pada kelenturan tubuh yang dilatih secara terus menerus.

Latihan merupakan salah satu teknik pembelajaran yang berorientasi pada peningkatan keterampilan. Dalam keterampilan melakukan senam lantai Filosofis yang mendasarinya bahwa keterampilan seseorang dapat ditingkatkan melalui pembiasaan. Secara teknis proses pembiasaan dapat dilakukan melalui latihan.

\section{METODE PENELITIAN}

\section{Jenis Penelitian}

Sesuai dengan judul, rumusan masalah dan tujuan penelitian maka jenis penelitian ini adalah Penelitian Tindakan Kelas (PTK). PTK adalah penelitian yang dilakukan oleh guru di dalam kelasnya sendiri melalui refleksi diri, dengan tujuan untuk memperbaiki kinerjanya sebagai guru, sehingga hasil belajar siswa menjadi meningkat (Arikunto,2006; 4).

\section{Tempat dan WaktuPenelitian}

Penelitian ini akan dilakukan di

SDN 3 Kopang dilaksanakan pada bulan Juli Sampai dengan September 2018, dilaksanakan pada semester I tahun pelajaran 2018 / 2019.

\section{Subjek Penelitian}

Subjek penelitian ini adalah siswa kelas IV SDN 3 Kopang yang berjumlah 13 siswa terdiri dari 7 siswa laki - laki dan 6 siswa perempuan, mereka berasal dari sekitar wilayah pinggir pasar jelojok kopang ,kecamatan Kopang.

\section{Prosedur Penelitian}

Penelitian ini akan dilaksanakan dalam dua siklus dalam tiap siklus akan dilakukan beberapa tahap yaitu: Perencanaan, pelaksanaan, pengamatan, refisi dan refleksi

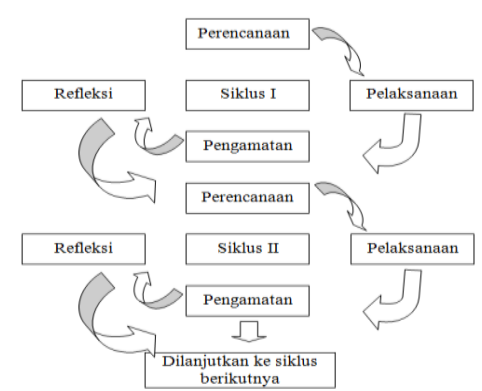

\section{Teknik Analisis Data}

Untuk lebih jelasnya kegaitan analisis data ini di lakukan dengan mengelompokkan Semua data yang diperoleh dari pre test, pos test maupun dari kegiatan observasi. Didalam menganalisis data hasil belajar akan digunakan format ketuntasan individu dan ketuntasan klasikal. Data yang sudah terkumpul akan dianalisis dengan formulasi:

$$
\mathrm{N}=\frac{\mathrm{S}}{\mathrm{SM}} \mathrm{-} \text {----- } 100
$$

Keterangan:

$$
\begin{aligned}
& \text { N = Nilai } \\
& \text { SM = Skor maksimal } \\
& \text { S = Jumlah skor dipolehan } \\
& 100=\text { Nilai tetap }
\end{aligned}
$$

\section{HASIL PENELITIAN DAN PEMBAHASAN \\ siklus I}

Dari hasil penelitian dapat dijelaskan bahwa dengan menerapkan pola latihan berulang diperoleh nilai rata-rata hasil belajar siswa adalah 67,6 pada siklus I ketuntasan belajar mencapai $31 \%$ atau 4 siswa sudah tuntas belajar dari 13 siswa dan siswa yang belum tuntas sebanyak 9 orang dengan persentase ketidak tuntasan sebesar $69 \%$, ini dikarenakan guru masih belum bisa memamfaatkan waktu dengan baik sehingga tujuan masih belum tercapai. Begitu juga dengan ketuntasan klasikal yang di persyaratkan sebesar $\geq 80$ belum tercapai maka dengan demikian penelitian dilanjutkan ke siklus berikutnya.

\section{siklus II}

Dari hasil analisa data paada siklus II setelah dilakukan perbaikan pembelajaran dapat dijelaskan bahwa dengan menerapkan pola latihan berulang diperoleh nilai rata-rata hasil belajar siswa 85,61 pada 
siklus II dengan ketuntasan belajar mencapai $92 \%$ atau ada 12 siswa sudah tuntas belajar dan 1 orang belum tuntas dengan persentase sebesar $8 \%$., bisa memamfaatkan waktu dengan baik. Begitu juga dengan ketuntasan klasikal yang di persyaratkan sebesar $\geq 80$ sudah tercapai maka dengan demikian penelitian ini dihentikan sampai pada siklus II.

\section{Pembahasan Hasil Penelitian}

Penelitian ini dilaksanakan di SDN 3 Kopang Kelas IV dengan materi Senam pada semester I tahun pelajaran 2018 / 2019 dengan jumlah Subyek penelitian sebanyak 13 orang dan hasilnya seperti yang telihat pada Bab IV yaitu sebagai berikut :

Hasil belajar siswa pada siklus I dengan menerapkan pola latihan berulang diperoleh nilai rata-rata hasil belajar siswa adalah 67,6 pada siklus I ketuntasan belajar mencapai 31 $\%$ atau 4 siswa sudah tuntas belajar, dan siswa yang belum tuntas sebanyak 9 orang dengan persentase ketidak tuntasan sebesar $69 \%$, ini dikarenakan guru masih belum bisa memamfaatkan waktu dengan baik sehingga tujuan masih belum tercapai. Begitu juga dengan ketuntasan klasikal yang di persyaratkan sebesar $\geq 80$ belum tercapai maka dengan demikian penelitian dilanjutkan ke siklus berikutnya.

Dari hasil analisa data dapat dijelaskan bahwa dengan menerapkan pola latihan berulang diperoleh nilai rata-rata hasil belajar siswa 85,61 pada siklus II dengan ketuntasan belajar mencapai $92 \%$ atau ada 12 siswa sudah tuntas belajar dan 1 orang belum tuntas dengan persentase sebesar $8 \%$., bisa memamfaatkan waktu dengan baik. Begitu juga dengan ketuntasan klasikal yang di persyaratkan sebesar $\geq 80$ sudah tercapai maka dengan demikian penelitian ini dihentikan sampai pada siklus II.

Dari hasil belajar yang diperoleh dari siklus I ke siklus II terus menunjukkan peningkatan hasil yang signifikan, dimana pada siklus I diperoleh rata - rata hasil belajar mencapai 67,6 kemudian meningkat pada siklus II menjadi 85,61 , terjadi peningkatan sebesar 18 poin, kemudian jumlah siswa yang tuntas belajar pada siklus I sebanyak 4 orang dengan persentase sebesar $31 \%$, kemudian pada siklus II jumlah siswa yang tuntas belajar sebanyak 12 orang dengan persentase sebesar $92 \%$ terjadi peningkatan sebesar 61 poin, demikian juga dengan ketuntasan klasikal yang dipatok sebesar $\geq 80 \%$ juga sudah tercapai, maka dengan demikian, semua indikator yang dipersyaratkan sudah terpenuhi maka penelitian ini dihentikan sampai pada siklus II.

Dengan demikian dapat ditarik kesimpulan bahwa dengan menggunakan metode latihan berulang dapat meningkatkan hasil belajar Senam lantai di Kelas IV SDN 3 Kopang tahun Pelajaran 2018 / 2019.

\section{KESIMPULAN}

Penelitian ini dilaksanakan di SDN 3 Kopang tahun pelajaran 2018 / 2019 dengan subyek penelitian sebanyak 13 siswa terdiri dari 7 siswa laki - laki dan 6 siswa perempuan. Berdasarkan data yang terkumpul dan analisis data yang telah dilakukan didapatkan peningkatan hasil belajar siswa baik dari rata-rata maupun ketuntasan klasikal.

Dari hasil belajar yang diperoleh dari siklus I ke siklus II terus menunjukkan peningkatan hasil yang signifikan, dimana pada siklus I diperoleh rata - rata hasil belajar mencapai 67,6 kemudian meningkat pada siklus II menjadi 85,61 , terjadi peningkatan sebesar 18 poin, kemudian jumlah siswa yang tuntas belajar pada siklus I sebanyak 4 orang dengan persentase sebesar $31 \%$, kemudian pada siklus II jumlah siswa yang tuntas belajar sebanyak 12 orang dengan persentase sebesar $92 \%$ terjadi peningkatan sebesar 61 poin, demikian juga dengan ketuntasan klasikal yang dipatok sebesar $\geq 80 \%$ juga sudah tercapai, maka dengan demikian, semua indikator yang dipersyaratkan sudah terpenuhi maka penelitian ini dihentikan sampai pada siklus II.

Dengan demikian dapat ditarik kesimpulan bahwa dengan menggunakan metode latihan berulang dapat meningkatkan hasil belajar Senam lantai di Kelas IV SDN 3 Kopang tahun Pelajaran 2018 / 2019. 
$\underline{n d e x}$

\section{DAFTAR PUSTAKA}

Akhadiah, Sabarti, dkk. 2001 Pembinaan Kemampuan Menulis Bahasa Indonesia, Jakarta: ErLangga

Arifin, E Zaenal dan Farid Had. 2003 Seribu Satu Kesalahan Baebahasa. Jakarta: Akademika Presinda.

Arikunto, Suharsimi, Prof. 2006. Penelitian Tindakan Kelas. Jakarta. Bumi Aksara.

Depdikbud RI. 2003. Kamus Besar Bahasa Indonesia. Jakarta: Balai Pustaka.

Keraf, Gorys. 2000. Argumentasa dan Narasi. Jakarta: PT. Gramedia

Kridalaksana, Harimurti. 1984. Kamus Linguistik. Jakarta: PT. Gramedia

Moeliono, 2000. Tata Bahasa Baku Bahasa Indonesia. Jakarta: Balai Pustaka.

Parera, Jos Daniel. 2004. Menulis Tertib dan Sistimatik. Jakarta: Erlangga

Suriamiharja, Agus 2006 "Kemampuan dan Keterampilan menulis Mahasiswa IKIP Bandung”. Tesis FPS IKIP Bandung

Tarigan, Henry Guntur. 2006. Pengajaran Sintaksis. Bandung: Angkasa. http://minwarno.blogspot.com). 